\title{
ПРОДОВОЛЬСТВЕННЫЙ ВКЛАД РЯЗАНСКОЙ ОБЛАСТИ В ВЕЛИКУЮ ПОБЕДУ
}

\section{FOOD CONTRIBUTION OF THE RYAZAN REGION TO THE GREAT VICTORY}

S. Zhevalov

Summary: The article is devoted to the study of the supply of agricultural products for all sources of income of the Ryazan region during the Great Patriotic war. The materials contained in the funds of the Russian state archive of Economics, which are first introduced into scientific circulation, formed the basis of this article. From documentary archival data, the total number of agricultural products of the Ryazan region delivered to the state in 1941-1945 is determined. The relevance of the article is due to the constantly reviving discussions about the importance of the contribution to the Great Victory of domestic agricultural supplies. The author comes to the conclusion that the collective-state farm system of farming in rural areas managed to provide the Red Army and the Soviet people with the necessary amount of bread, potatoes, vegetables, meat, milk, eggs, etc.

Keywords: Soviet Union; Great Patriotic war of 1941-1945; Ryazan region; Soviet collective farm-state farm village; grain procurement; delivery of agricultural products.
Жевалов Сергей Анатольевич

Соискатель, ФГБОУ ВО «Московский педагогический государственный университет» szhevalov@mail.ru

Аннотация: Статья посвящена изучению поставок продуктов сельскохозяйственного производства по всем источникам поступлений Рязанской области в период Великой Отечественной войны. Материалы, содержащиеся в фондах Российского государственного архива экономики (РГАЭ), которые впервые вводятся в научный оборот, легли в основу настоящей статьи. Из документальных архивных сведений определяется общее количество сельхозпродуктов Рязанской области, поставленных государству в 1941-1945 гг. Актуальность изложенной статьи обусловлена постоянно возрождающимися обсуждениями о значимости вклада в Великую Победу отечественных поставок сельхозпродуктов. Автор приходит к выводу, что колхозно-совхозная система хозяйствования на селе сумела обеспечить Красную Армию и Советский народ необходимым количеством хлеба, картофеля, овощей, мяса, молока, яиц и др.

Ключевые слова: Советский Союз, Великая Отечественная война 1941-1945 гг., Рязанская область, советская колхозно-совхозная деревня, заготовки зерна, поставки сельскохозяйственной продукции.
И сследование советского опыта сельскохозяйственных поставок продовольствия во время Великой Отечественной войны имеет огромное научное и практическое значение. В период войны в СССР были найдены и воплощены в жизнь правильные методы и пути верного использования внутренних источников Советского государства.

Историография данной проблемы взяла свое начало непосредственно в годы войны. Уже тогда увидели свет работы, опубликованные партийными и советскими деятелями нашей страны. В этих трудах авторы на единичных примерах показывали расширение сельскохозяйственного производства Союза ССР в годы войны.

Практически сразу после окончания войны, в 1947 году, появилась книга Н.А. Вознесенского «Военная экономика СССР в период Отечественной войны» [3]. В этой фундаментальной работе по продовольственной проблеме была раскрыта экономическая жизнь Советского государства во всей целостности и многогранности.

В 1960-1965 гг. коллективом научных сотрудников составлена и опубликована «История Великой Отечественной войны Советского Союза 1941-1945» [4]. В этом 6-томном исследовании, наряду с боевыми операциями, сделано подробное освещение экономической жизни страны, а также трудовой вклад в Великую победу колхозно-совхозной деревни.

В 1963 году вышла в свет монография Ю.В. Арутюняна «Советское крестьянство в годы Великой Отечественной войны» [1]. В своей работе автор доказал, что в 19411943 гг. в сельскохозяйственном производстве нашего государства был спад. Рост начался в 1944 году.

Книга «Советская экономика в период Великой Отечественной войны, 1941-1945 гг.» [11] была напечатана в 1970 году. В этом труде большое внимание уделено сельскохозяйственному производству в СССР, а также продемонстрированы общие поставки продуктов питания.

В 5-томном исследовании «История крестьянства СССР. История Советского крестьянства» [5] продовольственная проблема в период войны рассматривается и анализируется в третьем томе.

Работа Я.Е. Чадаева «Экономика СССР в годы Великой Отечественной войны 1941-1945 гг.» [14], как и книга Н.А. Вознесенского, предстал важным источником про- 
блемы, так как автор был непосредственным участником событий и опубликовал первичные материалы и собственные наблюдения.

В 2011 году вышла из печати работа Н.И. Рыжкова «СССР и Германия: битва экономик» [10], которая встала в один ряд с комплексными исследованиями экономических факторов Победы Союза ССР над гитлеровской Германией.

К 70-летию Великой Победы создан труд «Великая Отечественная война 1941-1945 годов» [2]. Седьмой том этого издания охватил оборонные и экономические возможности Советского государства, а также нацистской Германии.

В 2018 году напечатаны второй и третий тома международного исследования «Страна в огне. Коренной перелом. 1942-1943» [12] и «Страна в огне. Освобождение. 1944-1945» [13]. Первый том «1941 год. Страна в огне» вышел в 2011 году. В этих работах основная часть посвящена рассмотрению боевых действий. Но в них уделено достаточно много внимания состоянию общей экономики Советского государства, а также экономики сельскохозяйственного производства.

Анализ научной работы предшественников позволяет выделить вопросы, которые необходимо более детально изучить. Рассекреченные архивные документы позволяют уточнить изученные вопросы, расширить и углубить ранее исследованные темы, а также неизученные проблемы.

В фондах Российского государственного архива экономики находятся документы, которые воспроизведены в виде таблицы 1. В ней подробно расписаны поступления зерновых и бобовых в распределении по сельскохозяйственным культурам.

По величинам таблицы 1 видим, что в 1941-1945 гг. сельскохозяйственные труженики Рязанской области поставили государству более 1,3 млн. тонн зерна. Причем пшеницы и ржи - самых ценных зерновых культур страна получила почти 853 тыс. тонн или 65\% от суммарного количества хлеба, сданного Рязанской областью.

Далее, по таблице 1 видно, что в 1941 году общие поступления зерновых составили более 223,4 тыс. тонн. Этого хлеба было в 1,7 раза меньше, чем Советский Союз получил от области в 1940 году (381,4 тыс. тонн [7]).

В 1942 году колхозники и работники совхозов области почти в 1,5 раза увеличили хлебосдачу в сравнении с предыдущим годом, но в 1943 заготовки зерновых снизились в 1,6 раза против 1942 года. В 1944 году поставки зерна Рязанской области возросли в 1,5 раза относительно заготовок 1943 года, но в 1945 году снова сократились в 1,6 раза в сравнении с поступлениями хлеба в 1944 году.

В таблице 2 воспроизведем поставки животноводческих продуктов Рязанской области в 1940-1945 гг.

Во время Великой Отечественной войны работники сельскохозяйственного производства Рязанской области поставили стране более 70,7 тыс. тонн мяса в живом весе и почти 200 тыс. тонн молока. Советский Союз в период 1941-1945 гг. получил от области 371 центнер брынзы-сыра и свыше 65 млн. шт. яиц.

Таблица 1.

Поставки зерна Рязанской области в 1941-1945 гг., (в тоннах) [6]

\begin{tabular}{|c|c|c|c|c|c|}
\hline Зерновые культуры & 1941 г. & 1942 г. & 1943 г. & 1944 г. & 1945 г. \\
\hline Пшеница & 27795 & 32144 & 22803 & 23041 & 30540 \\
\hline Рожь & 167482 & 257685 & 60391 & 159550 & 71125 \\
\hline Овес & 17821 & 39629 & 83257 & 110446 & 84700 \\
\hline Ячмень & 297 & 2554 & 5940 & 5041 & 6847 \\
\hline Просо & 3018 & 4653 & 24527 & 20070 & 3104 \\
\hline Гречиха & 568 & 1613 & 2278 & 2051 & 335 \\
\hline Горох & 844 & 1051 & 2915 & 2296 & 1430 \\
\hline Фасоль & - & - & - & 10 & - \\
\hline Чечевица & 668 & 303 & 616 & 937 & 711 \\
\hline Кукуруза & - & - & - & - & 234 \\
\hline Полба & - & - & - & 128 & 7 \\
\hline Зерносмесь и отходы & 4930 & 2071 & 12883 & 7109 & 4570 \\
\hline Итого & 223423 & 341703 & 215610 & 330679 & 203603 \\
\hline
\end{tabular}


Таблица 2.

Заготовки животноводческих продуктов Рязанской области в 1940-1945 гг., в тоннах [8]

\begin{tabular}{|l|c|c|c|c|c|c|}
\hline Продукты животноводства & 1940 г. & 1941 г. & 1942 г. & 1943 г. & 1944 г. & 1945 г. \\
\hline Мясо & 19450 & 12488 & 22231 & 11443 & 10481 & 14086 \\
\hline Молоко & 70542 & 63293 & 33476 & 34801 & 30933 & 36972 \\
\hline Брынза-сыр (в цент.) & - & - & 12 & 166 & 146 & 47 \\
\hline Яйца (тыс. шт.) & 11010 & 12016 & 12426 & 9459 & 16717 & 14525 \\
\hline
\end{tabular}

Таблица 3.

Поступление продуктов полеводства Рязанской области в период Великой Отечественной войны, в тоннах [9]

\begin{tabular}{|c|c|c|c|c|c|}
\hline Культуры полеводства & 1941 г. & 1942 г. & 1943 г. & 1944 г. & 1945 г. \\
\hline Картофель & 195471 & 233442 & 275096 & 254529 & 128240 \\
\hline Сахарная свекла & 2970 & 14960 & 17610 & 11710 & 5730 \\
\hline Овощи, в том числе: & 31221 & 51049 & 59626 & 46990 & 36748 \\
\hline Капуста & 9610 & 26378 & 24410 & 26500 & 20950 \\
\hline Лук репчатый & 4120 & 4096 & 9470 & 4290 & 5150 \\
\hline Огурцы & 11200 & 5039 & 10940 & 5500 & 3110 \\
\hline Помидоры & 3600 & 3041 & 4680 & 2760 & 1360 \\
\hline Морковь & 1360 & 1080 & 2240 & 2120 & 2090 \\
\hline Свекла столовая & 900 & 4378 & 4100 & 3190 & 1760 \\
\hline Прочие овощи & 431 & - & - & 666 & 230 \\
\hline Фрукты семечковые & 14 & 12 & 4 & 11 & 480 \\
\hline \multicolumn{6}{|l|}{ Масличные, в том числе: } \\
\hline Подсолнечник & 1 & 59 & 367 & 380 & 42 \\
\hline Горчица & 41 & 164 & 116 & 247 & 52 \\
\hline Лен-кудряш & - & 15 & 1 & 2 & - \\
\hline Рыжик & - & - & 3 & 1 & - \\
\hline Мак & - & - & 4 & - & - \\
\hline
\end{tabular}

По величинам таблицы 2 видим, что в 1942 году от Рязанской области государство получило на 14\% больше мяса, чем в 1940 году. Однако, в 1943-1945 гг. видно резкое уменьшение поставок областью мяса и молока. Это связано с эвакуацией и забоем скота в 1941-1942 гг.

Обратим внимание на показатели таблицы 3, в которой собраны все поступления полеводческой сельскохозяйственной продукции от Рязанской области за период Великой Отечественной войны.

По цифрам таблицы 3 определяем, что в период с 1941 по 1945 гг. колхозно-совхозная деревня Рязанской области сдала государству почти 1,1 млн. тонн картофеля, а также 53 тыс. тонн сахарной свеклы.

Также в годы войны сельскохозяйственные труженики Рязанской области заготовили стране более 225,6 тыс. тонн овощей. В том числе капусты - почти 108 тыс. тонн, лука репчатого - 27,1 тыс. тонн, огурцов - 35,8 тыс. тонн, помидоров - 15,4 тыс. тонн, почти 9 тыс. тонн моркови, свыше 14,3 тыс. тонн свеклы столовой и 1,3 тыс. тонн прочих овощей.

От Рязанской области воюющий Советский Союз получил в 1941-1945 гг. 521 тонну фруктов.

Крестьяне и работники совхозов Рязанской области поставили Союзу ССР в 1941-1945 гг. 849 тонн подсолнечника, 620 тонн горчицы, 18 тонн льна-кудряша, а также по 4 тонны рыжика и мака.

Рассмотрев поступления сельскохозяйственных продуктов от Рязанской области, можно сделать следующие выводы.

Если в довоенное время для улучшения качественных показателей сельского хозяйства была специализация земледелия, то в период Великой Отечественной войны от сложившейся прежде специализации пришлось 
отказаться. Новое размещение сельскохозяйственных культур часто было вынужденным. Республики, края и области Советского Союза, которые до войны не специализировались на производстве зерновых, в военное время переквалифицировались на выращивание хлеба. В довоенные годы Рязанская область специализировалась на производстве картофеля и овощей. Во время войны область также оставалась одним из главных по- ставщиков этих сельскохозяйственных продуктов. Вместе с тем по таблице 1 видим, что в Рязанской области во втором и третьем периодах войны сильно выросли заготовки овса и проса. Из урожая 1945 года поступления проса сократились в сравнении с 1943-1944 гг. Таким образом, следы войны в размещении зерновых культур уже в конце её начали исчезать. Довоенная структура посевов быстро восстанавливалась.

\section{ЛИТЕРАТУРА}

1. Арутюнян Ю.В. Советское крестьянство в годы Великой Отечественной войны. М.: Издательство Академии наук СССР, 1963. 460 с.

2. Великая Отечественная война 1941-1945 годов. В 12-ти т. М.: Кучково поле, 2014. Т. 7.864 с.

3. Вознесенский Н.А. Военная экономика СССР в период Отечественной войны. М.: Госполитиздат, 1947. 192 с.

4. История Великой Отечественной войны Советского Союза 1941-1945. В 6-ти томах. М.: Военное издательство Министерства 0бороны СССР, $1960-1965$. T. $6.624 \mathrm{c}$.

5. История крестьянства СССР. История Советского крестьянства. В пяти томах. М.: Наука, 1986-1988. Т. 3.448 с.

6. Российский государственный архив экономики (РГАЭ). Ф. 8040. Народный комиссариат заготовок СССР. 0п. 3: Д. 749. Л. 10-12; Д. 865. Л. 5-6, 51-52, 66-68; Д. 865 а. Л. 5-6, 9-10, 22; Д. 980. Л. 2; Д. 982. Л. 3-5; Д. 987. Л. 98-99; Д. 1108. Л. 21, 25-28, 62-63; Д. 1116. Л. 2-3; Д. 1117. Л. 32-33; Д. 1126. Л. 155-156, 166-168, 237-238; Д. 1151. Л. 5, 226-227; Д. 1307. Л. 140-145; Д. 1308. Л. 1-3.

7. РГАЭ. Ф. 8040. ОП. З: Д. 749. Л. 10-12; Д. 865. Л. 51-52, 67-68; Д. 865 а. Л. 5-6, 9; Д. 982. Л. 5; Д. 987. Л. 98-99; Д. 1108. Л. 21, 62-63; Д. 1116. Л. 2-3; Д. 1117. Л. 32-33; Д. 1126. Л. 155-156, 166-168, 237-238; Д. 1151. Л. 5, 226-227.

8. РГАЭ. Ф. 8040. Оп. З: Д. 65. Л. 198-201; Д. 65а. Л. 200-201; Д. 683. Л. 52-58, 68; Д. 814. Л. 1, 10; Д. 803. Л. 12-14, 18-19, 22-28, 30, 33-34, 40-42, 51-59, 83; Д. 816. Л. 3-4; Д. 820. Л. 1-2; Д. 821. Л. 1-2, 8; Д. 929. Л. 31-33; Д. 931. Л. 4-10; Д. 935. Л. 1-2, 57-58; Д. 937. Л. 32; Д. 938. Л. 1-2; Д. 939. Л. 30-31; Д. 1022. Л. 65-66; Д. 1022а. Л. 38, 69-70; Д. 1032. Л. 71-72, 77-79; Д. 1068. Л. 1-2, 63; Д. 1069. Л. 1-2; Д. 1070. Л. 1-2; Д. 1081. Л. 1-2, 37-39; Д. 1082. Л. 49, 60-62; Д. 1151. Л. 23-24; Д. 1151а. Л. 25-26, 59-62, 65-66; Д. 1242. Л. 1-2, 94; Д. 1244. Л. 31-32; Д. 1341. Л. 48-51, 54-55; Д. 1384. Л. 1-2, 21-22; Д. 1441. Л. 1-10; Д. 1442. Л. 1-2; Д. 1447. Л. 15; Д. 1448. Л. 3-4, $98-99$.

9. РГАЭ. Ф. 8040. ОП. З: Д. 296. Л. 1-18; Д. 479. Л. 40; Д. 639. Л. 1, 13; Д. 768. Л. 1, 21-23; Д. 772. Л. 25; Д. 773. Л. 1; Д. 775. Л. 8; Д. 776. Л. 1-3; 60; Д. 777. Л. 5-6; Д. 778. Л. 1-5; Д. 781. Л. 1; Д. 879. Л. 1-4, 20-29; Д. 881. Л. 4, 10-11, 21; Д. 882. Л. 1-2, 25, 35-36; Д. 883. Л. 25; Д. 885. Л. 2-3; Д. 995. Л. 5, 7, $15 ;$ Д. 996. Л. 1-2; Д. 998. Л. 25-26; Д. 1000. Л. 1-2, 5-6, 9-10; Д. 1004. Л. 3; Д. 1007. Л. 1-5; Д. 1009. Л. 3; Д. 1124. Л. 1-3; Д. 1128. Л. 16; Д. 1131а. Л. 17-19; Д. 1136. Л. 1-4; Д. 1138. Л. 1-6; Д. 1141. Л. 1-2; Д. 1313. Л. 1-2, 7-8, 28-29; Д. 1318. Л. 8; Д. 1319. Л. 1-4; Д. 1320. Л. 16; Д. 1321. Л. 1-2; Д. 1323. Л. 1-4; Д. 1324. Л. 1-2; Д. 1443. Л. 3-4; Д. 1534. Л. 4, 5, 10-12; Д. 1892. Л. 1.

10. Рыжков Н.И. Великая Отечественная: битва экономик и оружие Победы / Н.И. Рыжков. М.: Издательский дом «Экономическая газета», 2011.448 с.

11. Советская экономика в период Великой Отечественной войны 1941-1945 гг. / ред. И.А. Гладков. М.: Наука, 1970. 504 с.

12. Страна в огне: В 3 т. Т. 2. Коренной перелом. 1942-1943: В 2 кн./ Отв. ред. Литвин А.М., Никифоров Ю.А. - М.: «Абрис», 2018.734 с.

13. Страна в огне: В 3 т. Т. З. Освобождение. 1944-1945: В 2 кн. / Отв. ред. Литвин А.М., Мягков М.Ю. - М.: «Абрис», 2018. 717 С.

14. Чадаев Я.Е. Экономика СССР в годы Великой Отечественной войны (1941-1945 гг.) / Я.Е. Чадаев. 2-е изд., перераб. и доп. М.: Мысль, 1985. 494 с.

๔ Жевалов Сергей Анатольевич (szhevalov@mail.ru). 